\title{
Pleural fluid plasmacytosis in a patient with plasma cell leukemia
}

\author{
Plazma hücreli lösemi hastasında plevral sıvı plazmasitozu
}

\author{
Raihan Sajid, Bushra Moiz, Nausheen Kamran, Salman Naseem Adil \\ Department of Pathology and Microbiology, Aga Khan University, Karachi, Pakistan
}

Plasma cell Leukemia ( $P C L$ ) is a rare disorder characterized by malignant proliferation of plasma cells in peripheral blood and bone marrow. There are two forms of PCL: the primary form occurring in patients without preceding multiple myeloma or monoclonal gammopathy of undetermined significance, and the secondary form arising as a leukemic transformation of multiple myeloma [1].

A 55 years old lady presented in hematology clinic with complaints of fever, cough and bone pains since last 8 months. General physical examination was unremarkable except for pallor. Initial investigations showed hemoglobin: $9.6 \mathrm{gm} / \mathrm{dl}$, hematocrit: $27.6 \%$, MCV: $88 \mathrm{fl}, \mathrm{MCH}: 27 \mathrm{pg}$, white blood cells: $11.5 \times 109 / \mathrm{L}$ and platelets: $356 \times 109 / \mathrm{L}$. Peripheral film showed normochromic normocytic anemia with marked rouleux formation. Diffuse infiltration with atypical and pleomorhic plasma cells was observed on subsequent bone marrow examination. Serum immunofixation showed $\lg G$ kappa monoclonal gammopathy. Serum IgG levels were $56.6 \mathrm{~g} / \mathrm{L}$ and skeletal survey demonstrated multiple lytic lesions in the skull. Creatinine level at diagnosis was $114 \mu \mathrm{mol} / \mathrm{L}$ and calcium was $2.5 \mathrm{mmol} / \mathrm{L}$. Based on her clinico-pathological manifestations, a diagnosis of multiple myeloma (stage IIIA according to Durie and Salmon classification) was made and the patient was started on thalidomide and dexamethasone.

However, unable to tolerate the treatment due to fatigue and somnolence, she presented again with shortness of breath and productive cough in one month time. This time, her chest X-ray revealed left sided pleural effusion along with right sided hydropneumothorax. Hilar vascular congestion and a posterolateral erosive lesion in fifth right rib were also evident. (Figure 1). Subsequent pleural tap drained off 1200 $\mathrm{ml}$ of fluid from each side. Pleural fluid analysis an exudative picture with numerous red cells with leukocyte count of 1900 $\mathrm{mm}^{3}$ and pleural fluid cytology exhibited malignant plasma cells. (Figure 2). This was not secondary to a traumatic tap as most of the cells were plasma cells and the differential in the peripheral blood was quite different as described below. Immuno-histochemistry demonstrated CD 138 positive plasma cells (Figure 3 ). Complete blood counts showed $\mathrm{Hb}$ $7.7 \mathrm{~g} / \mathrm{dl}$, WBC $10.1 \times 10^{3} / \mu \mathrm{L}$, Neutrophils 14\%, Lymphocytes 56\%,Plasma cells 22\%;Monocytes:8\% and Eosinophils 0\% and platelets $55 \times 10^{6} / \mathrm{L}$. Peripheral film examination showed $22 \%$ plasma cells consistent with transformation to plasma cell leukemia. Serum albumin was $2.3 \mathrm{~g} / \mathrm{dl}$ at the time of pleural tap and no evidence of renal failure was present at the time of progression of disease.

Patient was treated with one cycle of thalidomide (reduced dosage at $100 \mathrm{mg} /$ day) and dexamethasone as she refused for more aggressive chemotherapy and was discharged on this treatment but was lost to follow up.

PCL constitutes $2 \%$ to $4 \%$ of all cases of plasma cell disorders. The WHO criterion for diagnosis of PCL is that plasma cells constitute more than $20 \%$ of cells in the peripheral blood with an absolute plasma cell count of more than $2,000 \mathrm{~mm}^{3}$ [2]. The primary form which arise de novo constitutes $60 \%$ of all cases while secondary type represents leukemic transformation of myeloma. Overall response to treatment is poor with median survival of less than one year. Pleural fluid plasmacytosis in association with plasma cell leukaemia has been reported infrequently in literature [3, 4]. Review of local literature also revealed few cases of plasma cell leukaemia [5,6]. 


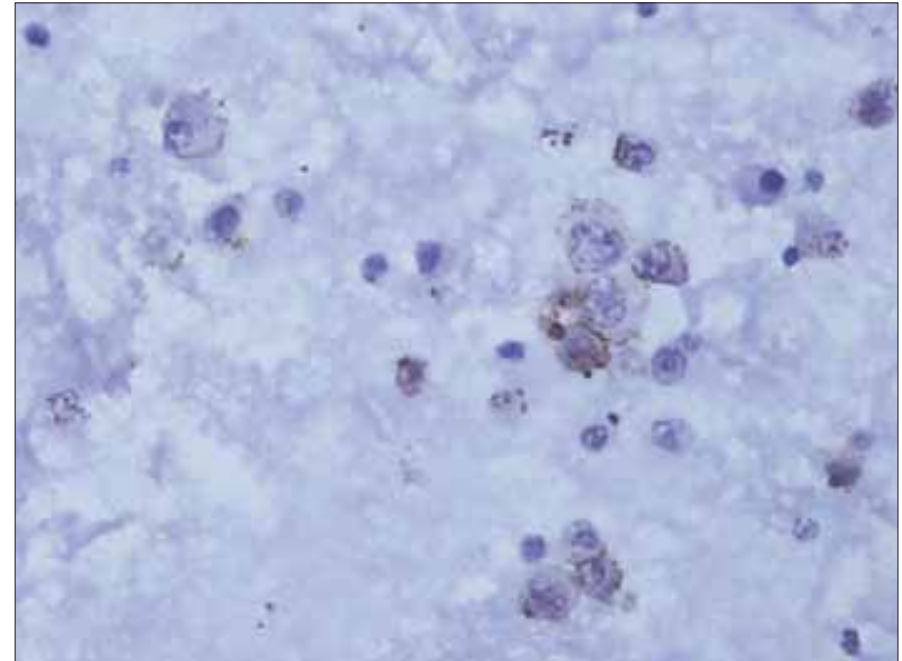

Figure 1. CD 138 on pleural fluid

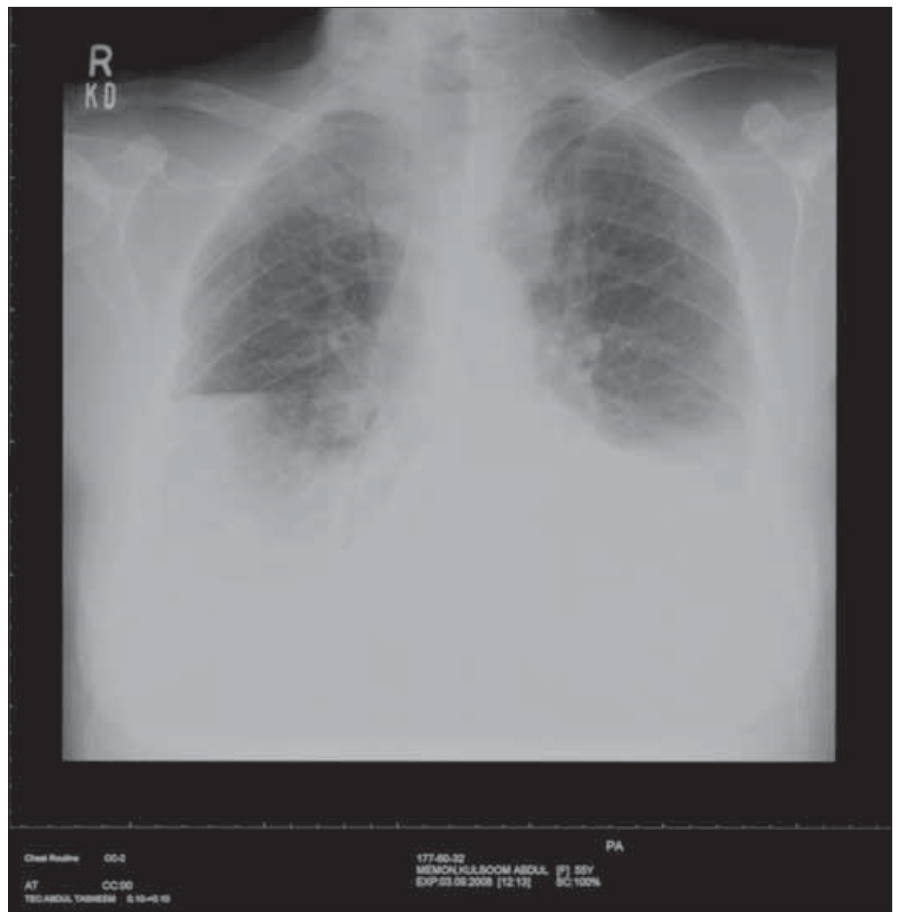

Figure 2. Chest $X$ ray

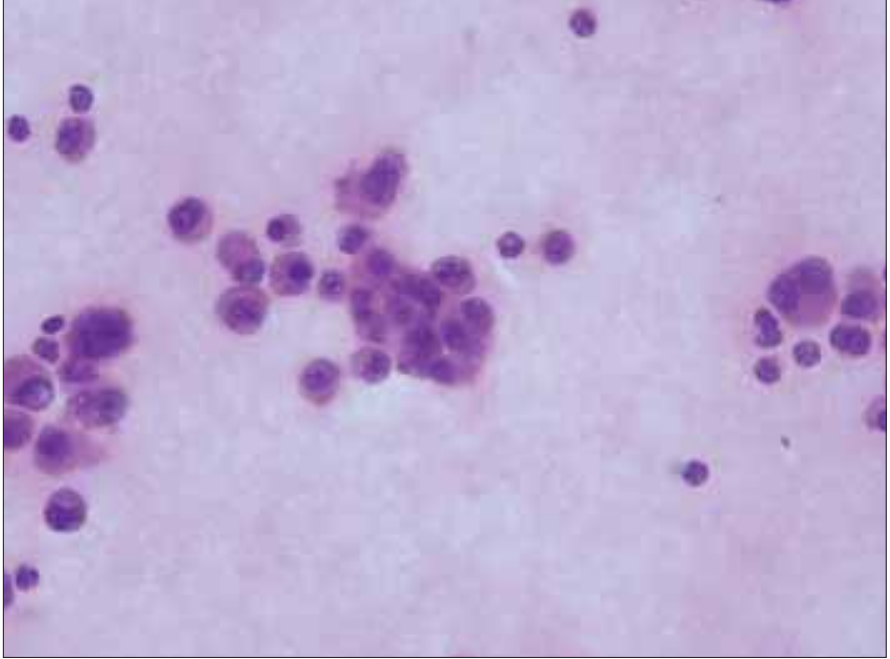

Figure 3. Pleural fluid plasmacytosis

Our patient was initially diagnosed with multiple myeloma; however she transformed to plasma cell leukaemia and also developed pleural fluid plasmacytosis. Pleural fluid plamacytosis seems to be an expression of this aggressive disease with poor outcome in most case reports and case series despite treatment.

\section{References:}

1. J imenez-Zepeda VH, Dominguez VJ. Plasma cell leukemia: a rare condition. Annals of hematology 2006;85:263-277.

2. Kyle RA, Maldonado JE, Bayrd ED. Plasma cell leukemia. Report on 17 cases. Archives of internal medicine1974; 133:813-8.

3. Alexandrakis MG, Passam FH, Kyriakou DS, Bouros D. Pleural effusions in hematologic malignancies. Chest 2004; 125:1546-55.

4. Suresh Attili BU, Devi Lakshm, P. P. Bapsy, K. C. Lakshm, K. Govind, D. Lokana, Saini Kamal, G. Anupam. Malignant myelomatous pleural effusion-ls onset of effusion a new prognostic factor? Turk J Hemato. 2007; 4:181-5.

5. Prabhat D, Bijur SJ , Pathare AV. Plasma cell leukaemia--a report of two cases. J ournal of postgraduate medicine. 1998; 44:47-9.

6. Raj RS, Najeeb S, Aruna R, Pavithran K, Thomas M. Primary plasma cell leukemia occuring in the young. Indian journal of cancer 2003; 40:116-7. 